\title{
Relationship between unemployment rate and shadow economy of selected mena countries: a toda -yamamoto and panel causality approach
}

\section{Rizgar Abdlkarim Abdlaziz}

Department of Management Technique, Technical College of Administration TCA, Sulaimani Polytechnic University, Sulaimani, Kurdistan Region, Iraq

Corresponding Author: rizgarabdlkarim@gmail.com

\section{Faisal Ali Khurshid}

Department of Economics, Faculty of Economics and Management, Sulaimani University, Sulaimani Kurdistan Region, Iraq

fa.khurshed@googlemail.com

\section{Prof. Dr. Hatem Hatef Abdulkadhim Altaee}

Department of Accounting, Faculty of Administration and Financial Sciences, Cihan University Sulaimaniya, Sulaimani, Kurdistan Region, Iraq

hatm.hatf@sulicihan.edu.krd

\section{ARTICLE INFO}

\section{Article History:}

Received: 2/10/2020

Accepted: 9/11/2020

Published: Winter 2020

\section{Keywords:}

Unemployment Rate, Shadow Economy,

MENA Countries,

Causality.

\section{ABSTRACT}

This research is an attempt to investigate the causal relationship between the shadow economy and unemployment rate for selected Middle East and North African countries. The Toda -Yamamoto causality approach and panel Granger causality test are applied. The Toda Yamamoto results reveal bidirectional causality for Algeria only. However, unidirectional causality running from unemployment to shadow economy found for Turkey and Qatar, the vice versa for Bahrain, Jordan, and Lebanon. Moreover, the panel Granger causality results show bidirectional causality for the MENA region when one and three lags are used. Nevertheless, unidirectional causality running from the shadow economy to the unemployment rate is found when two, four, and five lags are used. 


\section{Doi:}

10.25212/lfu.qzj.5.4.32

\section{INTRODUCTION}

According to the world bank data, Middle East and North Africa region witnessed the highest total and youth unemployment rate in the world, in the past decades (Kabbani, 2019). Increasing unemployment rate considers being one of the most significant challenges for governments in the region. Creating jobs in these economies for a massive number of graduated young people every year required healthy, diversified, and sustained economies (O'Sullivan and Mendez, 2011). Therefore, one of the utmost challenges of these countries is job creation, which needs political, economic, and institutional reforms to guaranty better living standards. However, the region still faces dramatic conflicts and political instabilities that regularly affect the economic outcome, such as employment and institutional structure (Fakih, Haimoun, and Kassem, 2020).

As shown in figure 1, the youth unemployment rate in the MENA region greater than that of Eurozone and around two times higher than that of South Asia and North American regions. In particular, in some MENA countries, the unemployment rate among young people frightfully increase, for instance, as average from 2000 to 2017, Libya witnessed 48 percent, Algeria and Egypt were about 30 percent of youth people were unemployed. (World Bank 2020) see appendix 1. 


\section{QALAAI ZANISTSCIENTIFIC JOURNAL \\ A Scientific Quarterly Refereed Journal Issued by Lebanese French University - Erbil, Kurdistan, Iraq}

Vol. (5), No (4), Winter 2020

ISSN 2518-6566 (Online) - ISSN 2518-6558 (Print)

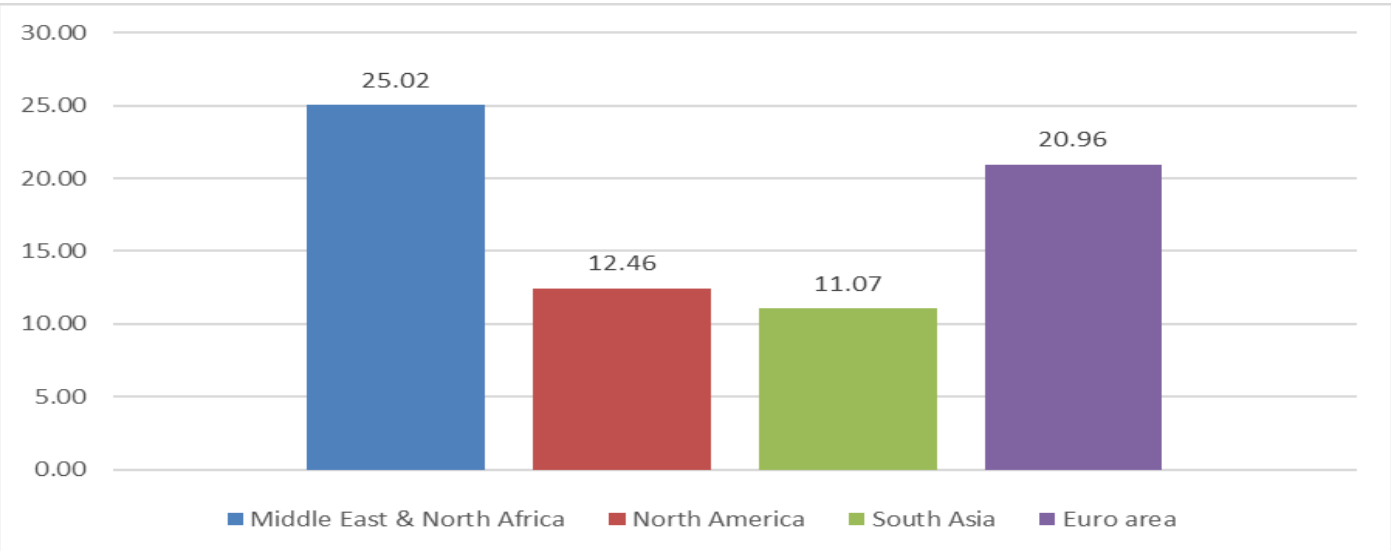

Figure 1. Youth Unemployment rate (\%of total Labor forces ages (15-24). Source: Authors 'calculation based on data from World Bank World Development Indicators 2020.

Unemployment rate can be considered as the root and causes of different types of socioeconomic and political unfavorable problems. Badimon, (2013) shows that the primary reasons for Arab spring were poverty, lack of economic opportunities, and unemployment, particularly youth unemployment. Additionally, there are plenty of studies that have exposed the correlation between unemployment and different type of crime (Raphael and Winter-ebmer, 2001). In this regard, the shadow economy, which includes hidden, unobserved, and informal economy, considers that one illegal economic activity can mostly be described as criminal activities (OECD, 2017). May the unemployment rate incentive this type of economic activity, especially in developing countries.

Shadow economy includes different economic activities, such as unregistered activities, illegal employment, social fraud, and criminal economic activities like money laundering and tax evasion. It comprises three types of economic activities, first, non-market activities, second, illegal activities lastly legal but unregistered economic activities due to tax avoidance(Schneider, and Enste, 2013).

Nowadays, the shadow economy and its consequences on economic performance were extensively discussed. Due to the dramatic growth of unemployment in some 


\section{QALAAI ZANISTSCIENTIFIC JOURNAL \\ A Scientific Quarterly Refereed Journal Issued by Lebanese French University - Erbil, Kurdistan, Iraq \\ Vol. (5), No (4), Winter 2020 \\ ISSN 2518-6566 (Online) - ISSN 2518-6558 (Print)}

regions, researchers and scholars focused on the discussion of different types of shadow economies such as modern slavery (Paraskevas, 2020), tax evasion (Dell, Anamaria, and Alexandru, 2019 and Vousinas, 2017), and all other forms of the informal economy(Goel, Saunoris, and Schneider, 2019).

Based on the fact that most of the MENA countries depend on the oil revenue to fuel economic growth and support public spending, the government sector has represented majorities in the labor market in the region. Therefore, the private sector will be small and weak; as a result, informal employment and the hidden economy tend to rise, especially after dramatic conflicts results from Arab spring (Chen and Harvey, 2017). As shown in Figure 2, the shadow economy as a percentage of GDP in the selected MENA countries in our sample study ranged from 15.9 for Qatar to 34.2 for Egypt. In general, the shadow economy in most MENA countries two times greater than most western countries.

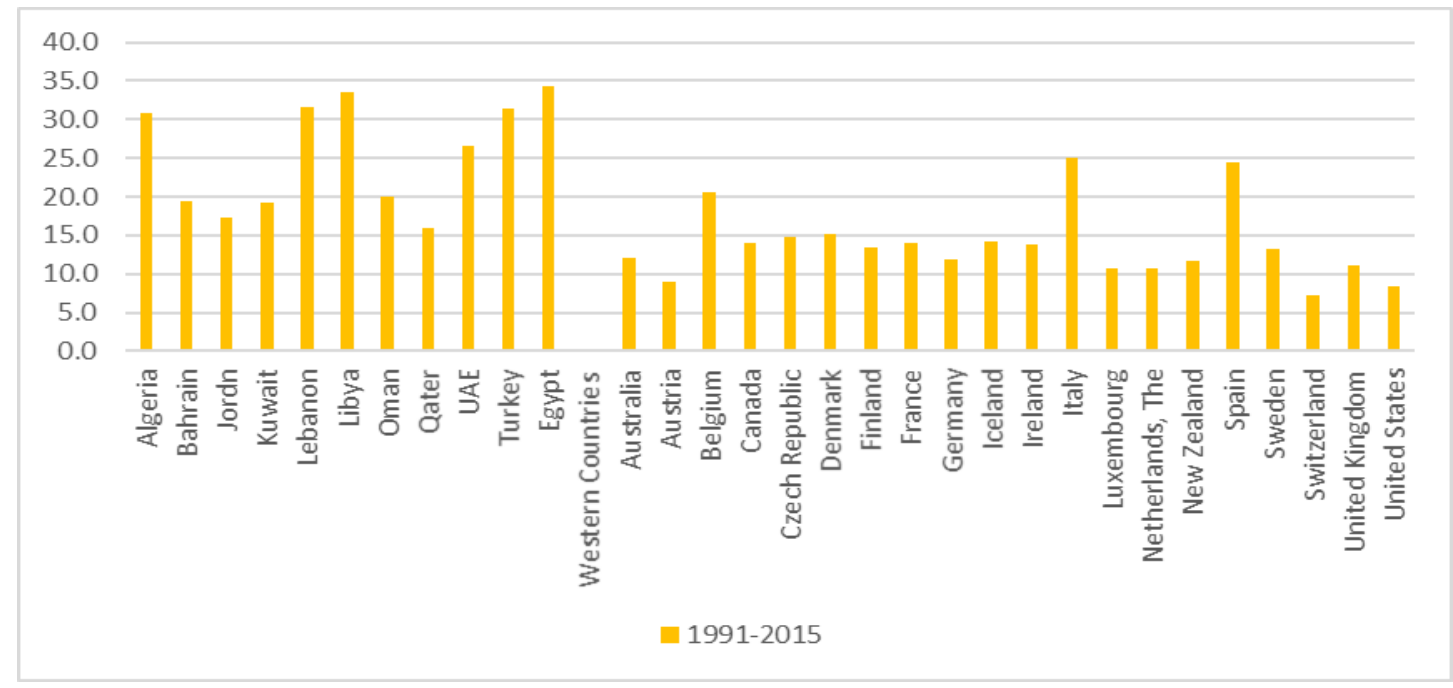

Figure 2. Shadow Economy as a percentage of GDP for MENA and Western Countries. (Average 1991-2015.

Source: Authors 'calculation based on data from (Medina and Schneider, 2018) 


\section{QALAAI ZANISTSCIENTIFIC JOURNAL \\ A Scientific Quarterly Refereed Journal Issued by Lebanese French University - Erbil, Kurdistan, Iraq \\ Vol. (5), No (4), Winter 2020 \\ ISSN 2518-6566 (Online) - ISSN 2518-6558 (Print)}

The present study tries to examine the causal relationship between the shadow economy and unemployment for selected MENA countries. To the best of our knowledge, very few researches concentrate on the topic of the region.

The remainder of this paper is organized as follows: The next section provides reviews of the literature extensively and presents the gap of the literature. Section 3 describes the empirical methodology for the research objective. Section 4 presents the estimated results and discussions. Finally, part 5 draws the conclusion and offers policy recommendations, along with the limitations of the study and directions for future research.

\section{2- $\quad$ Literature Review}

\subsection{Theoretical Review}

There is a continued debate about the relationship between the shadow economy and the unemployment rate among researchers. Glies and Tedds (2002) affirmed that two opposing forces determine the relationship between the unemployment rate and the Shadow economy. First, an increase in the unemployment rate may decrease the informal economy and the informal economy's positively related to GDP's growth rate. Additionally, the GDP growth rate is negatively associated with the unemployment rate. Conversely, an increase in the unemployment rate may cause rising people working in the underground economy because of their much free time for these activities.

Tanzi ( 1999).stated that the relationship between unemployment and the Shadow economy is ambiguous because sometimes people are officially employed. At the same time, they are involved in informal activities. Thus, Tanzi indicated that the official unemployment rate might have weakly related to the shadow economy.

Dell'Anno,Gomez-Antonio and Pardo (2007) declared that even though the economic theory does not provide concrete views on whether the expected sign of the relationship is positive or negative, we believe that there is a positive causal 


\section{QALAAI ZANISTSCIENTIFIC JOURNAL \\ A Scientific Quarterly Refereed Journal Issued by Lebanese French University - Erbil, Kurdistan, Iraq \\ Vol. (5), No (4), Winter 2020 \\ ISSN 2518-6566 (Online) - ISSN 2518-6558 (Print)}

relationship between unemployment and the shadow economy. Therefore, an increase in the unemployment rate leads to a rise in the Shadow economy.

Besides unemployment people, self-employment as a share of the labor force is considered an essential determinant of the Shadow economy. Studies show that growth in the number of small businesses and more self-employed people probably contribute primarily to enhancing the shadow economy's level. due to the fact that small business and self-employed people work very closely with their customers, they can cooperate with them in the evasion of indirect taxes. (Bordignon, and Zanardi,1997; Williams and Horodnic,2015).

\subsection{Empirical Review}

Shadow economy and the unemployment rate relationships have extensively investigated for developed countries. Schneider, Raczkowski, and Mróz (2015) applied the Multiple Indicators Multiple Causes (MIMIC) method to analyze the size shadow economy of 31 European countries for 2014 and 28 European Union countries for 2003-2014. The researchers found that indirect taxes were the primary determinant of the shadow economy, and then self-employment and unemployment were considered significant driving forces of the shadow economy. In the case of Greece, Vousinas (2017) examined the factors that determined tax avoidance and the informal economy. Among sets of factors, he found that selfemployment and the unemployment rate were played the most significant role in the rise of the size of the shadow economy and tax evasion. Dell et al. (2019) concluded that to reduce the Shadow economy and tax evasion in Romania economy, the policymaker should consider monitoring and observe the unemployment rate and self-employment.

Schneider and Buehn (2012) investigate the factors that influence the growth and development the size of the shadow economy for 39 developed OECD economies. They exhibited that the unemployment rate, self-employment, and tax burden were considered the main driving forces for the shadow economy. more particularly, indirect taxes had a significant impact by (29.4\%) on Shadow economy, followed by 


\section{QALAAI ZANISTSCIENTIFIC JOURNAL \\ A Scientific Quarterly Refereed Journal Issued by Lebanese French University - Erbil, Kurdistan, Iraq \\ Vol. (5), No (4), Winter 2020 \\ ISSN 2518-6566 (Online) - ISSN 2518-6558 (Print)}

self-employment (22\%) and Unemployment rate (16\%). Bajada and Schneider (2009) previously found that long term employment contribute in the shadow economy for OECD countries.

Sometimes the effect of employment and unemployment varies from region to another inside the same countries. Bertola, and Garibaldi (2002) found that average shadow employment rate differences over the 20 Italian areas, they found that the average is about 10 percent in the south and 30 percent in the south. In this regards the quality of institutions and social norms having a significant role in the regions. Fialová and Schneider, (2011) explore the impact of the labor Institutions on the shadow economy for European countries in two different perspectives, Shadow production, and shadow employment. Their results confirm theoretical and empirical studies that stricter employment protection legislation drives shadow production and employment.

In Romania's case, several studies tried to expose the causality relationships between shadow economies and unemployment. Adriana (2014) applied the TodaYamamoto method to investigate the causal relationships between the Shadow economy and the unemployment rate. The results of modified Wald (MWald) tests support unidirectional causality runs from the unemployment to the shadow economy. In another study, Davidescu and Dobre, (2013) using ARDL approach to investigate the impact of the unemployment rate on the size of the informal economy for Romania economies, they found that unemployment rate have a negative impact on the size of Shadow economy in the short run while the effect was positive for the long run. In the case of U.S.A economies, Alexandru and Dobre ( 2012) provided the same results which is unemployment have unidirectional effect on Shadow economy.

Sahnoun and Abdennadher (2019) using a simultaneous-equation model for 78 developed and developing countries to investigate the causal relationship between the shadow economy and unemployment. They found negative and unidirectional causality running from unemployment to shadow economy for developing 


\section{QALAAI ZANISTSCIENTIFIC JOURNAL \\ A Scientific Quarterly Refereed Journal Issued by Lebanese French University - Erbil, Kurdistan, Iraq \\ Vol. (5), No (4), Winter 2020 \\ ISSN 2518-6566 (Online) - ISSN 2518-6558 (Print)}

economies. However, there is a bidirectional and negative causal relationship between the shadow economy and the unemployment rate in developed countries.

In the case of MENA countries, studies concentrate only on estimating the size of the shadow economy. Mansour and Zaki (2019) estimated the size of the shadow economy in Egypt and the other eight developing MENA countries from 2000 to 2017 using the Multiple Indicators Multiple Causes (MIMIC) approach. Warde ( 2007) focused on the impact of war on terrors and crimes on the shadow economy for MENA countries. They expose that war on terrors has created 'gated economic communities' and expanded the size of the shadow economy. Based on our knowledge, there is no single study investigating the causal relationship between unemployment and the Shadow economy for MENA countries. Therefore, the existing studies try to fill this gap by using the Toda-Yamamoto approach to examine the causality relations between shadow economies and Unemployment rate.

\section{3- Data and Methodology}

In achieving its objective, the study concentrates on the Middle East and North Africa (MENA) countries with annual data during the period 1991 to 2015. Namely, Algeria, Libya, Egypt, Jordon, Qatar, Bahrain, Oman, United Arab Emirates, Kuwait, Lebanon, and Turkey. Other MENA countries have been excluded due to the unavailability of the data on unemployment rate. Size of Shadow economy as percentage of the GDP used as a proxy of the shadow economy variable. Data on the shadow economy is obtained from (Medina and Schneider, 2018), The data on the unemployment rate is collected from macrotrends database, which refers to the unemployment rate to the share of the labor force.

\section{3-1 Toda and Yamamoto}

To achieve the objective of this study, we concentrate on two different approaches: the first Toda -Yamamoto causality test for each country, secondly the panel causality test for nine MENA countries. The most basic method to examine the 
causalities between variables is the Granger-causality proposed by Granger (1969) which is estimating by simple Vector Autoregressions (VAR) as follow:

$$
\begin{aligned}
& U N_{t}=\sum_{i}^{n} \alpha_{i} S H_{t-i}+\sum_{j}^{n} \beta_{j} U N_{t-j}+U_{1 t} \\
& S H_{t}=\sum_{i}^{M} \lambda_{i} U N_{t-i}+\sum_{j}^{m} \delta_{j} S H_{t-j}+U_{2 t} .
\end{aligned}
$$

Where $(\mathrm{i})$ and $(\mathrm{j})=1$; U1t and $\mathrm{U} 2 \mathrm{t}$ are white noise processes.

In the Granger causality test, the lagged SH (shadow economy) significantly influenced UN (unemployment) as clarifying in equation 1. The lagged UN (unemployment) affects the SH (shadow economy) significantly in equation 2.The estimated lagged coefficients are jointly tested. If the F statistic test rejects the Null hypothesis that $\Sigma \alpha i$ and $\Sigma \lambda j$ both are not different from zero, that means the causal relationship between unemployment rate and shadow economy are confirmed. Traditional Granger causality test is simple and easy to apply in many empirical studies. However, it has various limitations. Firstly, causality test is sensitive to model specification and the number of lags. Secondly, non-stationary time-series data mostly cause spurious regression.

To overcome the limitations of the traditional Granger causality test, (Toda and Yamamoto (1995) introduced a simple and interesting method to test the causality between variables. The technique requires the estimation of an augmented VAR, which guarantees the asymptotic distribution of the Wald statistic (an asymptotic $\chi 2$-distribution), since the testing procedure is sound to the integration and cointegration properties of the process.

In this stage, we apply the modified Wald approach to test the VAR $(m+d m a x)$ model for causality.

$$
\begin{aligned}
& U N_{t}=a_{0}+\sum_{i=1}^{m} b_{1 i} U N_{t-i}+\sum_{i=m+1}^{m+\operatorname{dmax}_{b i}} b_{2 i} N_{t-i}+\sum_{j=1}^{m} c_{1 j} S H_{t-j}+ \\
& \sum_{j=m+1}^{m+\operatorname{dmax}} c_{2 j} S H_{t-j}+V_{1 t}
\end{aligned}
$$


$S H_{t}=d_{0}+\sum_{i=1}^{m} e_{1 i} S H_{t-i}+\sum_{i=m+1}^{m+d m a x} e_{2 i} S H_{t-i}+\sum_{j=1}^{m} f_{1 j} U N_{t-j}+$

$\sum_{j=m+1}^{m+d \max } f_{2 j} U N_{t-j}+V_{2 t}$

Where $(\alpha, b, c, d, e$, and $f)$ are coefficients of the estimated model

(dmax) is the maximum order of integration suspected to occur in the system, and $\mathrm{V} 1 \mathrm{t}$ and $\mathrm{V} 2 \mathrm{t}$ are the residual of the models.

The null hypothesis that SH (Shadow economy) does not cause UN (unemployment rate) is formed as follows:

$H_{0}: c_{1 i}=0$, where $i=1, \ldots . m$

Similar to the previous one, the null hypothesis in equation 4 is that the UN (unemployment rate) does not cause SH (shadow economy) is formed as follows:

$H_{0}: f_{1 i}=0, \quad$ where $i=1, \ldots . m$

With the implementation of the Toda Yamamoto model, two preliminary steps are required. The first one is the lag selection of the estimated model. Some criteria, such as Akaike Information Criterion (AIC), Schwarz Information Criterion (SC), Final Prediction Error (FPE), and Hannan-Quinn (HQ) Information Criterion, are used to determine the appropriate lag order of the VAR. The second step is to determine the maximum order of integration of the variables in the system. In this case, The Augmented Dickey-Fuller (ADF) and The Phillips-Perron (PP) Tests are employed. The null hypotheses of both tests are the variable is non-stationary.

\section{3-2 Panel causality}

After estimating the Toda- Yamamoto causality test for each series, this study uses the panel Granger causality test developed by Dumitrescu and Hurlin (2012). The panel causality test developed based on the individual Wald statistic of Granger 
non-causality averaged across the cross-section units, and the test study the the heterogeneity of causal relationships and the heterogeneity of the regression model used for testing Granger causality. the panel regression model formed as follow:

$U N_{t i}=\psi_{i}+\sum_{k=1}^{k} \omega^{k}{ }_{i} U N_{i t-k}+\sum_{k=1}^{k} \phi_{i}^{k} S H_{i t-k}+\varepsilon_{i t}$

$S H_{t i}=\theta_{i}+\sum_{k=1}^{k} \eta_{i}^{k} S H_{i t-k}+\sum_{k=1}^{k} \vartheta_{i}^{k} U N_{i t-k}+\mu_{i t}$

Where $(\psi, \omega, \phi, \theta, \eta$, and $\vartheta)$ are coefficients of the estimated panel regressions

(k) is the order of lags selection; $\varepsilon$ and $\mu$ are the residual of the panel models.

$i=1 \ldots N$ represents the cross section of individual countries, where $t=1 \ldots \ldots T$ denotes the time period

\section{3-2-1 Estimating Panel Unit Root}

Before applying the panel causality techniques, the stationarity of the data must be examined using panel unit root tests, and the order of integration of each variable being studied must be determined. Five panel unit root tests are applied: Im, Pesaran and Shin (2003), Levin, Lin and Chu (2002), Breitung (2000), augmented Dickey-Fuller (ADF) Fisher chi-squared test (ADF-Fisher) and PP Fisher chi-squared test (PP-Fisher) (Maddala and Wu, 1999). These tests are frequently applied to panel economic analysis. The LLC and IPS unit root tests are proposed on the basis of ADF statistics, which is averaged across the group. The LLC test assumes that the coefficients are homogenous for all cross-sectional units in the panel. The advantage of the IPS test is that it allows for heterogeneity in intercepts and slope terms for cross-section units. Serial correlation problems are also eliminated.

\section{4-Empirical Results}

As we mentioned above, this study designed to reach what has been intended in two ways: first by testing the causality between unemployment and shadow 


\section{QALAAI ZANISTSCIENTIFIC JOURNAL \\ A Scientific Quarterly Refereed Journal Issued by Lebanese French University - Erbil, Kurdistan, Iraq \\ Vol. (5), No (4), Winter 2020 \\ ISSN 2518-6566 (Online) - ISSN 2518-6558 (Print)}

economy with respect to each country and as a panel. In section 4.1 the results of each country will be discussed, and in section 4.2 the panel results will be explore.

\subsection{Country Results}

\subsubsection{Unit Root Results}

The present study tries to report the Toda -Yamamoto causality results in three steps, the first test to determine the order of integration of the variables. Second is the lag selection of regressions, and lastly, it tests for the causality relationship between the shadow economy and Unemployment by conducting the wald test.

Table (1) provides the results of the Augmented Dickey-Fuller (ADF) and the PhillipsPerron (PP) unit root test for the shadow economy and unemployment rate for eleven MENA countries. As shown in the table1, the Trend and Intercept results are mixed of I(0) and I (1). However, in the case of Intercept only, the results expose I(1) integrated variables for countries except Oman, Kuwait, and UAE. Therefore, we exclude these countries from the time series analysis and include them in the panel analysis. Thus, the maximum order of integration in the VAR system dmax=1. But due to saving the space, the second steps of the lag selection are provided with causality results in table 2 .

Table 1. Unit Root Test Results

\begin{tabular}{|c|c|c|c|c|c|c|c|c|c|}
\hline \multirow{3}{*}{$\begin{array}{l}\text { Cou } \\
\text { ntry }\end{array}$} & \multirow{3}{*}{$\begin{array}{c}\text { Vari } \\
\text { abl } \\
\text { e }\end{array}$} & \multicolumn{4}{|c|}{ Augmented Dicky fuller } & \multicolumn{4}{|c|}{ Phillip Peron } \\
\hline & & \multicolumn{2}{|c|}{ Level } & \multicolumn{2}{|c|}{ First difference } & \multicolumn{2}{|c|}{ Level } & \multicolumn{2}{|c|}{ First difference } \\
\hline & & $\alpha$ & $\mathrm{T} \& \alpha$ & $\alpha$ & $\mathrm{T} \& \alpha$ & $\alpha$ & $T \& \alpha$ & $\alpha$ & $T \& \alpha$ \\
\hline \multirow[t]{2}{*}{ DZA } & $\mathrm{SH}$ & -0.142 & $\begin{array}{c}- \\
4.1446^{*} \\
*\end{array}$ & $\begin{array}{c}- \\
3.026^{* *}\end{array}$ & -2.959 & -0.434 & -2.141 & $-2.922^{*}$ & -2.854 \\
\hline & UE & -0.344 & -2.249 & $\begin{array}{c}-3.673 \\
* *\end{array}$ & $\begin{array}{c}- \\
3.4756^{*}\end{array}$ & -0.574 & -2.760 & $-3.656^{* *}$ & $\begin{array}{c}- \\
3.451^{* *}\end{array}$ \\
\hline \multirow[t]{2}{*}{ BHR } & $\mathrm{SH}$ & -1.974 & -1.936 & $\begin{array}{c}- \\
3.421^{* *}\end{array}$ & -1.176 & -2.295 & -2.275 & $-3.494^{* *}$ & -3.2518 \\
\hline & UE & $-2.893^{*}$ & -2.819 & $\begin{array}{c}- \\
3.007^{* *}\end{array}$ & -2.935 & -2.105 & -2.051 & $-2.900^{*}$ & -2.832 \\
\hline JOR & $\mathrm{SH}$ & -0.920 & -1.854 & $\begin{array}{c}- \\
3.577^{* *}\end{array}$ & $-3.498^{*}$ & -1.208 & -1.445 & $-3.577^{* *}$ & $-3.498^{*}$ \\
\hline
\end{tabular}




\section{QALAAI ZANISTSCIENTIFIC JOURNAL}

A Scientific Quarterly Refereed Journal Issued by Lebanese French University - Erbil, Kurdistan, Iraq

Vol. (5), No (4), Winter 2020

ISSN 2518-6566 (Online) - ISSN 2518-6558 (Print)

\begin{tabular}{|c|c|c|c|c|c|c|c|c|c|}
\hline & UE & -2.421 & $4.135^{* *}$ & $\begin{array}{c}- \\
3.155^{* *}\end{array}$ & $-3.500^{*}$ & -2.371 & -1.917 & $-3.155^{* *}$ & $-3.495^{*}$ \\
\hline \multirow[t]{2}{*}{ LBY } & $\mathrm{SH}$ & -1.842 & -1.685 & $\begin{array}{c}- \\
6.735^{* *} \\
*\end{array}$ & $\begin{array}{c}- \\
6.885^{* *} \\
*\end{array}$ & -1.779 & -1.614 & $-6.722^{* * *}$ & $\begin{array}{c}- \\
{ }^{-} \\
{ }^{*}\end{array}$ \\
\hline & UE & -1.240 & -3.093 & $\begin{array}{c}- \\
3.073^{* *}\end{array}$ & -3.144 & -0.851 & -2.196 & $-3.093^{* *}$ & -3.169 \\
\hline \multirow[t]{2}{*}{$\begin{array}{l}\text { QA } \\
T\end{array}$} & $\mathrm{SH}$ & -1.011 & -2.073 & $\begin{array}{c}- \\
5.607^{* *} \\
*\end{array}$ & $\begin{array}{c}- \\
5.876^{* *} \\
*\end{array}$ & -0.923 & -1.991 & $-5.607^{* * *}$ & $6.302^{* *}$ \\
\hline & UE & -0.257 & $-3.398^{*}$ & ${ }^{-}{ }^{-}{ }^{* *}$ & $\begin{array}{c}- \\
3.828^{* *}\end{array}$ & -0.102 & -2.519 & -2.271 & -2.117 \\
\hline \multirow[t]{2}{*}{ EGY } & $\mathrm{SH}$ & -1.325 & -2.890 & $\begin{array}{c}- \\
3.751^{* *}\end{array}$ & $-3.611^{*}$ & -1.494 & -1.831 & $-3.750^{* *}$ & $-3.610^{*}$ \\
\hline & UE & -1.172 & $3.735^{* *}$ & $\begin{array}{c}- \\
4.086^{* *} \\
*\end{array}$ & $\begin{array}{c}- \\
4.150^{* *}\end{array}$ & -1.493 & -1.984 & $-4.288^{* * *}$ & $4.222^{-}$ \\
\hline \multirow[t]{2}{*}{$\begin{array}{c}\mathrm{OM} \\
\mathrm{N}\end{array}$} & $\mathrm{SH}$ & -1.367 & 0.848 & -2.294 & -2.924 & -1.603 & 0.481 & -2.219 & -2.902 \\
\hline & UE & 0.585 & -2.812 & -2.986 & $-3.312^{*}$ & 0.127 & -2.114 & $-2.682^{*}$ & -3.047 \\
\hline \multirow[t]{2}{*}{ LBN } & $\mathrm{SH}$ & -1.387 & -1.370 & $\begin{array}{c}- \\
3.349^{* *}\end{array}$ & $-3.311^{*}$ & -1.4980 & -1.802 & $-3.349^{* *}$ & $\begin{array}{c}- \\
3.311^{* *}\end{array}$ \\
\hline & UE & -0.608 & -1.999 & $\begin{array}{c}- \\
3.733^{* *}\end{array}$ & $\begin{array}{c}- \\
3.773^{* *}\end{array}$ & -0.802 & -2.140 & $-3.607^{* *}$ & $\begin{array}{c}- \\
3.659^{* *}\end{array}$ \\
\hline \multirow[t]{2}{*}{$\begin{array}{c}\mathrm{KW} \\
\mathrm{T}\end{array}$} & $\mathrm{SH}$ & -1.972 & -1.636 & $\begin{array}{c}- \\
4.435^{* *} \\
*\end{array}$ & $\begin{array}{c}- \\
4.770^{* *} \\
*\end{array}$ & -1.692 & -1.595 & $-4.428^{* * *}$ & $\begin{array}{c}- \\
4.719^{* *}\end{array}$ \\
\hline & UE & -0.618 & -3.046 & -2.801 & -2.459 & -0.681 & -2.406 & -2.344 & -1.8460 \\
\hline \multirow[t]{2}{*}{ UAE } & $\mathrm{SH}$ & -1.025 & -1.960 & $\begin{array}{c}- \\
4.783^{* *} \\
*\end{array}$ & $\begin{array}{c}- \\
4.613^{* *}\end{array}$ & -0.990 & -1.944 & $-4.783^{* * *}$ & $\begin{array}{c}- \\
4.613^{* *} \\
*\end{array}$ \\
\hline & UE & -1.730 & -0.822 & -2.4538 & $-3.394^{*}$ & -1.544 & 0.138 & -2.488 & -2.8323 \\
\hline \multirow[t]{2}{*}{ TUR } & $\mathrm{SH}$ & -1.423 & $-3.298^{*}$ & $\begin{array}{c}- \\
4.763^{* *} \\
*\end{array}$ & $4.393^{* *}$ & -1.307 & $-3.298^{*}$ & $-5.915^{* * *}$ & $\begin{array}{c}- \\
5.789^{* *} \\
*\end{array}$ \\
\hline & UE & -1.940 & -3.1943 & $\begin{array}{c}- \\
3.998^{* *} \\
*\end{array}$ & $\begin{array}{c}- \\
3.910^{* *}\end{array}$ & -2.093 & -2.493 & $-3.998^{* * *}$ & $\begin{array}{c}- \\
3.910^{* *}\end{array}$ \\
\hline
\end{tabular}

Notes: ${ }^{* * *}, * *, *$ Rejection of null hypothesis at the $1 \%, 5 \%$ and $10 \%$ level of significance, respectively. 


\section{QALAAI ZANISTSCIENTIFIC JOURNAL \\ A Scientific Quarterly Refereed Journal Issued by Lebanese French University - Erbil, Kurdistan, Iraq \\ Vol. (5), No (4), Winter 2020 \\ ISSN 2518-6566 (Online) - ISSN 2518-6558 (Print)}

\subsubsection{A Toda-Yamamoto results}

the results of the Toda -Yamamoto causality tests and diagnostics tests are reported in table (2) As shown in the table, in the case of Bahrain, Jordan, and Lebanon, there is evidence of unidirectional causality running from the shadow economy $(\mathrm{SH})$ to the unemployment rate (UE). In the case of Bahrain, the causality effect is large, statistically significant at $0.1 \%$ level, while the MWald results statistically significant at the $0.5 \%$ and $0.10 \%$ level for Jordan and Lebanon, respectively. That means an increase in the shadow economy will increase the unemployment rate, but not vice versa. The results do not consist with the theory, but one possible explanation for these results is the Tanzi 1999 views, which is stated that the official unemployment rate might have weakly related to the shadow economy, especially for these countries. However, in Qatar and Turkey, the MWald results indicate a unidirectional causality running from the unemployment rate to the shadow economy. The results statistically significant at the $0.10 \%$ and $0.5 \%$ levels for Qatar and Turkey, respectively. That means an increase in the unemployment rate will increase the shadow economy, but not vice versa. These results confirm previous empirical studies that found unidirectional causality runs from the unemployment rate to the shadow economy for the Romanian and United States economies (Adriana, 2014; Adriana \& Davidescu, 2013; Alexandru et al., 2012). The MWald results only reveal a bidirectional causal relationship between the shadow economy and the unemployment rate for Algeria. That means an increase in the unemployment rate will increase the shadow economy, and vice versa. The result for Algerian economy is similar to the finding of recent empirical study conducted by Sahnoun and Abdennadher (2019), for the developed economies.

The Toda- Yamamoto causality results expose no causal relationship between the unemployment rate and the Shadow economy for Libya and Egypt.

Table 2. Toda-Yamamoto Causality (Modified WALD) Test Results

\begin{tabular}{ccccccccc}
\hline \multicolumn{8}{c}{ MWald statistics } \\
\hline & ZDA & BHR & JOR & LBY & QAT & EGY & LBN & TUR \\
\hline $\mathrm{UE} \rightarrow \mathrm{SH}$ & $4.116^{* *}$ & 1.995 & 0.201 & 0.211 & $5.808^{*}$ & 0.524 & 0.756 & $5.00^{* *}$ \\
\hline
\end{tabular}




\begin{tabular}{lcccccccc}
\hline & $(0.042)$ & $(0.157)$ & $(0.902)$ & $(0.645)$ & $(0.0548)$ & $(0.469)$ & $(0.384)$ & $(0.025)$ \\
$\mathrm{SH} \rightarrow$ EU & $32.25 * * *$ & $8.824 * * *$ & $9.115^{* *}$ & 1.803 & 4.038 & 0.892 & $3.829 *$ & 0.97 \\
& $(0.000)$ & $(0.003)$ & $(0.01)$ & $(0.179)$ & $(0.1327)$ & $(0.344)$ & $(0.050)$ & $(0.32)$ \\
LM & 0.637 & 0.592 & 0.651 & 0.487 & 0.422 & 0.584 & 0.445 & 0.51 \\
Lag & 1 & 1 & 2 & 1 & 2 & 1 & 1 & 1 \\
AR Root & 0.890 & 0.740 & 0.921 & 0.820 & 0.916 & 0.966 & 0.826 & 0.9515 \\
\hline
\end{tabular}

Notes: $* * *, * *, *$ Rejection of null hypothesis at the $1 \%, 5 \%$ and $10 \%$ level of significance, respectively, and the values in parentheses are P-values.

The diagnostic tests of serial correlation and the stability of the VAR model are reported in the lower panel of the table. The LM test of Breush-Godfrey exposes that the models do not have a serial correlation in all cases.

AR roots show the stability of the VAR models in all cases. If all roots less than one and lie inside the unit circle, that means the VAR model is tables and stationary. However, the model is not stable if the roots are greater than one or outside the unit circle. AS shown in the table, AR Roots are less than one in all cases, which means the estimated VAR models in the study are stable.

\subsection{Panel Granger Causality Test Results}

\subsubsection{Panel Unit Root Results}

As a preliminary test to determine the order of integration of each variable, we apply five panel unit-roots we mentioned previously in the methodology section. Table (3) shows the results of the panel unit root for eleven MENA countries. Both the Shadow economy and the unemployment rate are integrated in I (1) order. That means in both intercept and intercept and trend, the results reject the null hypothesis of stationarity for first difference but not in level for all cases.

Table 3. Panel Unit Root Test Results

\begin{tabular}{|c|c|c|c|c|c|c|c|c|c|}
\hline & \multicolumn{4}{|c|}{ intercept } & \multicolumn{5}{|c|}{ Intercept and trend } \\
\hline & & & & & Level & & & & \\
\hline $\begin{array}{c}\text { Variabl } \\
\text { e }\end{array}$ & LLC & IPS & $\begin{array}{l}\text { ADF- } \\
\text { Fisher }\end{array}$ & $\begin{array}{l}\text { PP- } \\
\text { Fisher }\end{array}$ & LLC & $\begin{array}{c}\text { Breitung } \\
T\end{array}$ & IPS & $\begin{array}{l}\text { ADF- } \\
\text { Fisher }\end{array}$ & $\begin{array}{l}\text { PP- } \\
\text { Fisher }\end{array}$ \\
\hline SH & 0.343 & 0.766 & 12.70 & 14.34 & 2.086 & 0.990 & 1.455 & 13.841 & 13.194 \\
\hline
\end{tabular}




\section{QALAAI ZANISTSCIENTIFIC JOURNAL}

A Scientific Quarterly Refereed Journal Issued by Lebanese French University - Erbil, Kurdistan, Iraq

Vol. (5), No (4), Winter 2020

ISSN 2518-6566 (Online) - ISSN 2518-6558 (Print)

\begin{tabular}{|c|c|c|c|c|c|c|c|c|c|}
\hline UE & 0.864 & 1.303 & 16.33 & 13.88 & 0.145 & 0.340 & -2.513 & $39.84^{*}$ & 17.16 \\
\hline & \multicolumn{9}{|c|}{ First Difference } \\
\hline SH & $\begin{array}{c}- \\
9.149^{* *} \\
*\end{array}$ & $\begin{array}{c}- \\
10.01^{* *} \\
*^{*}\end{array}$ & $\underset{* *}{129.02^{*}}$ & $131.23^{*}$ & $\begin{array}{c}- \\
7.266^{* *} \\
*\end{array}$ & $-2.694^{* * *}$ & $\begin{array}{c}- \\
7.558^{* *} \\
*\end{array}$ & $94.73^{* *}$ & ${ }_{*}^{102.7^{* *}}$ \\
\hline UE & $\underset{*}{--}{ }^{-}$ & $\begin{array}{c}- \\
6.671^{* *}\end{array}$ & $83.15^{* * *}$ & $73.65^{* * *}$ & ${ }^{4.621^{* *}}$ & $-3.234^{* * *}$ & $\begin{array}{c}- \\
5.067^{* *}\end{array}$ & $\begin{array}{c}61.38^{* *} \\
*\end{array}$ & $\underset{*}{49.22^{* *}}$ \\
\hline
\end{tabular}

Notes: $* * *, * *, *$ Rejection of null hypothesis at the $1 \%, 5 \%$ and $10 \%$ level of significance, respectively.

\subsubsection{Lag Order Selection Criteria}

Before estimating equations number (5) and (6) for the panel Granger causality test, we selected the appropriate leg lengths. As shown in table (4), the Akaike Information Criterion (AIC), Schwarz Information Criterion (SC), Final Prediction Error (FPE), and Hannan-Quinn (HQ) Information Criterion are used to determine the appropriate lag order of the VAR. Based on the Schwarz Information Criterion (SIC) result, the optimal lags are one lag while Hannan-Quinn (HQ) Information Criterion indicates 2 lags. However, both the Akaike Information Criterion (AIC) and Final Prediction Error (FPE) show (8) lags. Then we estimate equations number (5) and (6) and examine panel Granger causality between variables under study at different lags.

\section{Table 4. Lag Order Selection Criteria Results}

\begin{tabular}{ccccc}
\hline Lag & FPE & AIC & SC & HQ \\
\hline \hline 0 & 1470.157 & 12.96888 & 13.00344 & 12.98288 \\
1 & 1.820755 & 6.275000 & $6.378672^{*}$ & 6.317008 \\
2 & 1.743429 & 6.231582 & 6.404369 & $6.301596^{*}$ \\
3 & 1.784223 & 6.254667 & 6.496568 & 6.352685 \\
4 & 1.761627 & 6.241843 & 6.552859 & 6.367867 \\
5 & 1.825640 & 6.277413 & 6.657543 & 6.431442 \\
6 & 1.842764 & 6.286571 & 6.735816 & 6.468606
\end{tabular}




\section{QALAAI ZANISTSCIENTIFIC JOURNAL \\ A Scientific Quarterly Refereed Journal Issued by Lebanese French University - Erbil, Kurdistan, Iraq}

Vol. (5), No (4), Winter 2020

ISSN 2518-6566 (Online) - ISSN 2518-6558 (Print)

\begin{tabular}{lllll}
7 & 1.719845 & 6.217297 & 6.735657 & 6.427337 \\
8 & $\mathbf{1 . 6 7 4 4 9 5 *}$ & $6.190259 *$ & 6.777734 & 6.428304 \\
\hline
\end{tabular}

The results of Pairwise Dumitrescu-Hurlin Panel Granger causality tests are presented in Table (5). According to the results, there is bidirectional causality between the Shadow economy and the unemployment rate when one and three lags are used. However, the unidirectional causality running from the shadow economy to the unemployment rate is found when $(2,4$, and 5$)$ lags are used.

\subsubsection{Pairwise Dumitrescu-Hurlin Panel Causality Tests}

The unemployment rate granger causes the shadow economy to be statistically significant at $0.10 \%$ and $0.5 \%$ level in lags 1 and 3 , respectively. In comparison, the results of the shadow economy granger cause the unemployment rate to be statistically significant in all cases, excluding lag number 6 is not statistically significant. The finding of the panel study confirmed previous empirical studies by Saafi, Farhat and Mohamed(2015) and Sahnoun and Abdennadher(2019),They found mixed results of bidirectional causality between the two variables under investigation and unidirectional causality running from unemployment rate to the shadow economy. However, the present study found strong unidirectional causality running from the shadow economy to the unemployment rate. That means, in MENA countries shadow economy causes the unemployment rate.

Table 5: Panel Causality Tests Results (Pairwise Dumitrescu-Hurlin )

\begin{tabular}{ccccl}
\hline Direction of Causality & Lags & MWald & P-value & Decision \\
\hline $\mathrm{UE} \rightarrow \mathrm{SH}$ & 1 & 2.02061 & 0.073 & reject the Null \\
$\mathrm{SH} \rightarrow \mathrm{UE}$ & 1 & 4.85903 & 0.000 & Reject the Null \\
$\mathrm{UE} \rightarrow \mathrm{SH}$ & 2 & 2.54938 & 0.697 & Do not reject the Null \\
$\mathrm{SH} \rightarrow \mathrm{UE}$ & 2 & 6.88209 & 0.000 & Reject the Null \\
\hline $\mathrm{UE} \rightarrow \mathrm{SH}$ & 3 & 5.721 & 0.027 & Reject the Null \\
$\mathrm{SH} \rightarrow \mathrm{UE}$ & 3 & 7.684 & 0.000 & Reject the Null \\
\hline $\mathrm{UE} \rightarrow \mathrm{SH}$ & 4 & 5.700 & 0.506 & Do no reject the Null \\
$\mathrm{SH} \rightarrow \mathrm{UE}$ & 4 & 10.88 & 0.000 & Reject the Null \\
\hline $\mathrm{UE} \rightarrow \mathrm{SH}$ & 5 & 6.921 & 0.7952 & Do no reject the Null \\
$\mathrm{SH} \rightarrow \mathrm{UE}$ & 5 & 11.96 & 0.0035 & Reject the Null \\
\hline
\end{tabular}




$\begin{array}{lllll}\mathrm{UE} \rightarrow \mathrm{SH} & 6 & 13.34 & 0.2150 & \text { Do no reject the Null } \\ \mathrm{SH} \rightarrow \mathrm{UE} & 6 & 11.76 & 0.4306 & \text { Do no reject the Null }\end{array}$

\section{5-Conclusions}

This study tries to examine the causal relationship between the shadow economy and unemployment for selected MENA countries during the period 1991 to 2015. Using the Toda -Yamamoto causality approach and panel Granger causality test developed by Dumitrescu and Hurlin (2012), the present study is the difference from the previous works in two dimensions: First, it focuses on MENA countries that have faced the highest unemployment rate and shadow economy compared to Europe. See (figure 1 and 2). And second is the methodological novelty using the Toda Yamamoto causality approach (time series data) and panel Granger causality to meet the objective of the study. To the best of our knowledge, very few researches concentrate on this topic with respect to this region. The first technique allows investigating the relationship between variables for each specific country and the second for the whole regions.

The Toda -Yamamoto causality expose mixed results. Unidirectional causality running from the shadow economy $(\mathrm{SH})$ to the unemployment rate is found for Bahrain, Jordan, and Lebanon. That means the shadow economy causes a rising of unemployment rate in these countries. However, the results reveal a unidirectional causality running from the unemployment rate to the shadow economy for Turkey and Qatar economies, which means that an increase of the unemployment rate leads to an increase in the underground economy in these countries. This finding approves the existing literature supporting a unidirectional causality that runs from unemployment rates to the shadow economy. Further, in the case of the Algerian economy, the empirical results display a bidirectional causality between the underground economy and the unemployment rate.

Furthermore, Dumitrescu and Hurlin (2012), Panel Granger causality tests are applied to investigate the causal relationship in the MENA region. The results of the panel analysis are robust to the Toda -Yamamoto results, indicating a bidirectional 


\section{QALAAI ZANISTSCIENTIFIC JOURNAL \\ A Scientific Quarterly Refereed Journal Issued by Lebanese French University - Erbil, Kurdistan, Iraq \\ Vol. (5), No (4), Winter 2020 \\ ISSN 2518-6566 (Online) - ISSN 2518-6558 (Print)}

causality between the two variables when using lag 1 and 3, that means one and three periods of causality between unemployment and shadow economy. Unidirectional causality running from the shadow economy to the unemployment rate when using different lags $(2,4$ and 5$)$. The results indicate that in the past periods, the shadow economy causes the unemployment rate.

\section{REFERENCES:}

Adriana, D., 2014. Revisiting the relationship between unemployment rates and shadow economy. A Toda-Yamamoto approach for the case of Romania. Procedia Economics and Finance, 10, pp.227-236 https://doi.org/10.1016/S2212-5671(14)00297-4

Alexandru, A.A., Dobre, I. and Ghinararu, C.C., 2012, July. The causal relationship between unemployment rate and US shadow economy. A Toda-Yamamoto approach. In Proceedings of the 5th international conference on Applied mathematics, simulation, modelling (pp. 100105).

Badimon, M.E., 2013. Does unemployment spark collective contentious action? Evidence from a Moroccan social movement. Journal of Contemporary African Studies, 31(2), pp.194212.

Bertola, G., \& Garibaldi.P, 2002. The Structure and History of Italian Unemployment. CESifo «Working Paper, Series, 907.

Bordignon, M., \& Zanardi, A. (1997). Tax evasion in Italy. Giornale degli economisti e annali di economia, 169-210.

Chen, M., Harvey, J. and Network, W.I.E.G.O., 2017. The informal economy in Arab nations: a comparative perspective. WIEGO Paper for Arab Watch Report on Informal Employment in MENA Region.

Schneider, F.and Bajada, C., 2009. Unemployment and the Shadow Economy in the OECD. Revue économique, 60(5), pp.1033-1067.

Davidescu, A. and Dobre, I., 2013. The relationship between shadow economy and unemployment rate. A ARDL causality analysis for the case of Romania. In Conference New Techniques and New Technologies for Statistics, (pp. 46-62).

Dell'Anno, R. and Davidescu, A.A., 2019. Estimating shadow economy and tax evasion in Romania. A comparison by different estimation approaches. Economic Analysis and Policy, 63, pp.130-149. https://doi.org/10.1016/i.eap.2019.05.002

Dell'Anno R., Gomez-Antonio, M. and A. Alanon Pardo (2007), Shadow Economy in three different Mediterranean Countries: France, Spain and Greece. A MIMIC Approach, Empirical Economics, 33, pp. 51-84. 


\section{QALAAI ZANISTSCIENTIFIC JOURNAL \\ A Scientific Quarterly Refereed Journal Issued by Lebanese French University - Erbil, Kurdistan, Iraq \\ Vol. (5), No (4), Winter 2020 \\ ISSN 2518-6566 (Online) - ISSN 2518-6558 (Print)}

Dumitrescu, E.I. and Hurlin, C., 2012. Testing for Granger non-causality in heterogeneous panels. Economic modelling, pp.1450-1460. https://doi.org/10.1016/j.econmod.2012.02.014

Fakih, A., Haimoun, N. and Kassem, M., 2020. Youth Unemployment, Gender and Institutions During Transition: Evidence from the Arab Spring. Social Indicators Research, pp.1-26.). https://doi.org/10.1007/s11205-020-02300-3

Fialová, K. and Schneider, O., 2011. Labor institutions and their impact on shadow economies in Europe. The World Bank. Policy Research Working Paper Series.

Goel, R.K., Saunoris, J.W. and Schneider, F., 2019. Growth in the shadows: effect of the shadow economy on US economic growth over more than a century. Contemporary Economic Policy, 37(1), pp.50-67. https://doi.org/10.1111/coep.12288.

Granger, C.W., 1969. Investigating causal relations by econometric models and crossspectral methods. Econometrica: journal of the Econometric Society, 37(3), pp.424-438.

Im, K.S., Pesaran, M.H. and Shin, Y., 2003. Testing for unit roots in heterogeneous panels. Journal of econometrics, 115(1), pp.53-74.

Kabbani, N., 2019. Youth employment in the Middle East and North Africa: Revisiting and reframing the challenge. Brookings Doha Center Policy Briefing, Doha, February.

Levin, A., Lin, C.F. and Chu, C.S.J., 2002. Unit root tests in panel data: asymptotic and finitesample properties. Journal of econometrics, 108(1), pp.1-24.

Maddala, G.S. and Wu, S., 1999. A comparative study of unit root tests with panel data and a new simple test. Oxford Bulletin of Economics and statistics, 61(S1), pp.631-652.

Mansour, A.M.A.E.A. and Zaki, I.M., 2019. Estimating the Size of the Shadow Economy in Nine MENA Countries during the Period 2000 to 2017 Using the MIMIC Model. Open Access Library Journal, 6(7), pp.1-14. https://doi.org/10.4236/oalib.1105508

Medina, L. and Schneider, F., 2018. Shadow economies around the world: what did we learn over the last 20 years? International Monetary Fund Working Paper WP/18/17.

O'Sullivan, A., Rey, M.E. and Mendez, J.G., 2011. Opportunities and Challenges in the MENA Region. Arab world competitiveness report, pp.42-67.

OECD, 2017. Shining Light on the Shadow Economy: Opportunities and Threats. Paris: OECD. Paraskevas, A. 2020. "Human Trafficking and Modern Slavery in Europe's hotels "In: C.

Lashley (Ed). Slavery and Liberation in hotels restaurants and bars, Oxford: Routledge ISBN: 978-0367424664.

Raphael, S. and Winter-Ebmer, R., 2001. Identifying the effect of unemployment on crime. The Journal of Law and Economics, 44(1), pp.259-283.

Saafi, S., Farhat, A. and Mohamed, M.B.H., 2015. Testing the relationships between shadow economy and unemployment: empirical evidence from linear and nonlinear tests. Studies in Nonlinear Dynamics \& Econometrics, 19(5), pp.585-608. https://doi.org/10.1515/snde2014-0021 


\section{QALAAI ZANISTSCIENTIFIC JOURNAL \\ A Scientific Quarterly Refereed Journal Issued by Lebanese French University - Erbil, Kurdistan, Iraq \\ Vol. (5), No (4), Winter 2020 \\ ISSN 2518-6566 (Online) - ISSN 2518-6558 (Print)}

Sahnoun, M. and Abdennadher, C., 2019. The nexus between unemployment rate and shadow economy: A comparative analysis of developed and developing countries using a simultaneous-equation model. Economics Discussion Papers (No. 2019-30). pp.1-27

Schneider, F. and Enste, D.H., 2013. The shadow economy: An international survey. Cambridge, United Kingdom, Cambridge University Press

Schneider, F., Raczkowski, K., \& Mróz, B., 2015. Shadow economy and tax evasion in the EU. Journal of Money Laundering Control, 18(1), pp. 34-51.

Schneider, F., \& Buehn, A. (2012). Shadow economies in highly developed OECD countries: What are the driving forces?. ? Discussion Paper, Department of Economics, University of Linz, Linz, Austria.

Tedds, L. M., \& Giles, D. E. (2002). Taxes and the Canadian underground economy. Taxes and the Canadian underground economy, Toronto: Canadian Tax Foundation.

Toda, H.Y. and Yamamoto, T., 1995. Statistical inference in vector autoregressions with possibly integrated processes. Journal of econometrics, 66(1-2), pp.225-250.

Vousinas, G.L., 2017. Shadow economy and tax evasion. The Achilles heel of Greek economy. Determinants, effects and policy proposals. Journal of Money Laundering Control 20(14). pp.386-404.

Williams, C. C., \& Horodnic, I. A. (2015). Self-employment, the informal economy and the marginalisation thesis. International Journal of Entrepreneurial Behavior \& Research, 21 (2), pp 224-242.

Warde, I., 2007. The war on terror, crime and the shadow economy in the MENA countries. Mediterranean Politics, 12(2), pp.233-248. https://doi.org/10.1080/13629390701398033.

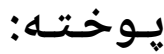

ئامانجى ئهم تويّزينهوهيه، دهستنيشانكردنى يهيوهنديى هوّكاريى نيّوان نابووريى سيّبهر و تيّكراى بيّكارييه له دهولَتانى خوّرههلاّتى ناوهراست و باكوورى ئهفريقا، به يهيرهوكردنى شيّوازى توّدا ياماموّتا ( .Toda -Yamamoto) تويّزينهوه دهريخست تهنها له جهزائر يهيوهندييهكى دوو ئاراسته له نيّوان ههردوو كوّراوهكهدا ههيه، له كاتيّا ئهو يهيوهندييه له ههر يهك له توركيا و قهتهر يهك ئاراستهيه و له بيّكارييهوه به ئاراستهى ئابووريى سيّبهر دهروات، يِيّجهوانهى ئهم ئاراستهيه له ههريه له ئوردن و لوبنانه. ويّرِاى ئهو دهرئهنجامانه، يهيوهندييهكى دوو ئاراسته له دهولّتانى خوّرههلاّتى ناوهراست و باكوورى ئهفريقا ههيه كاتيّك يهك ماوه يان سى ماوهى ( (agادواخستن 


\section{QALAAI ZANISTSCIENTIFIC JOURNAL}

A Scientific Quarterly Refereed Journal Issued by Lebanese French University - Erbil, Kurdistan, Iraq

Vol. (5), No (4), Winter 2020

ISSN 2518-6566 (Online) - ISSN 2518-6558 (Print)

بهكارهيِنرا، بهلام له كاتى بهكارهيّنانى دوو يان جوار يان بيِنج ماوهى دواخستن، يهيوهنديى هوّكاريى يهك ئاراسته بوو، له نابووريى سيبهرهوه بهرهو تيّكراى بيّكارى.

العلاقة السببية بين معدل البطالة واقتصاد الظل لبلدان مختارة في منطقة شرق الاوسط وشمال افريقا

$$
\text { بطريقة تودا - يامساموتو }
$$

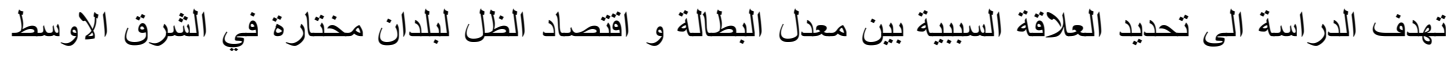

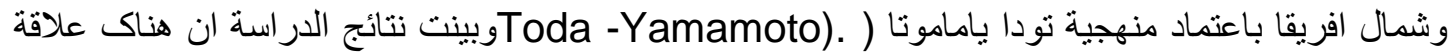

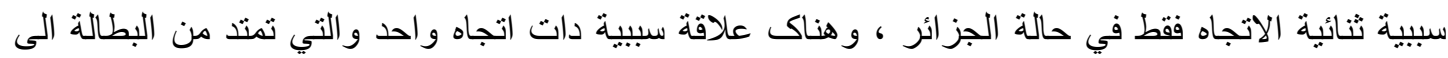

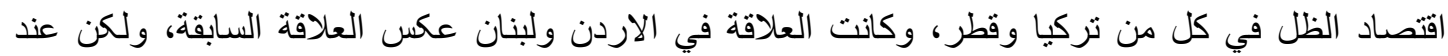

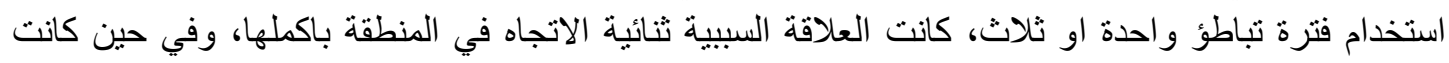

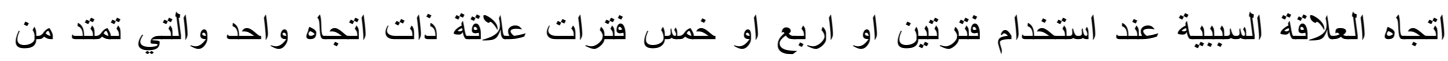

اقتصاد الظل الى معدل البطالة. 